\title{
Piperlongumine-Induced Phosphatidylserine Translocation in the Erythrocyte Membrane
}

\author{
Rosi Bissinger ${ }^{1}$, Abaid Malik ${ }^{1}$, Jamshed Warsi ${ }^{1}$, Kashif Jilani ${ }^{1,2}$ and Florian Lang ${ }^{1, *}$ \\ 1 Department of Physiology, Eberhard-Karls-University of Tuebingen, Gmelinstr. 5, \\ 72076 Tuebingen, Germany; E-Mails: ro.bissinger@gmx.de (R.B.); \\ malik.abaid@googlemail.com (A.M.); jamshedwarsi@yahoo.com (J.W.); \\ kashif_cbc@yahoo.com (K.J.) \\ 2 Department of Biochemistry, University of Agriculture, 38040 Faisalabad, Pakistan
}

External Editor: Vernon L. Tesh

* Author to whom correspondence should be addressed; E-Mail: florian.lang@uni-tuebingen.de; Tel.: +49-7071-29-72194; Fax: +49-7071-29-5618.

Received: 3 July 2014; in revised form: 2 September 2014 / Accepted: 24 September 2014 / Published: 14 October 2014

\begin{abstract}
Background: Piperlongumine, a component of Piper longum fruit, is considered as a treatment for malignancy. It is effective by inducing apoptosis. Mechanisms involved in the apoptotic action of piperlongumine include oxidative stress and activation of p38 kinase. In analogy to apoptosis of nucleated cells, erythrocytes may undergo eryptosis, the suicidal death of erythrocytes characterized by cell shrinkage and cell membrane scrambling with phosphatidylserine-exposure at the erythrocyte surface. Signaling involved in eryptosis include increase of cytosolic $\mathrm{Ca}^{2+}$-activity $\left(\left[\mathrm{Ca}^{2+}\right]\right.$ ), formation of ceramide, oxidative stress and activation of p38 kinase. Methods: Cell volume was estimated from forward scatter, phosphatidylserine-exposure from annexin $\mathrm{V}$ binding, $\left[\mathrm{Ca}^{2+}\right]_{i}$ from Fluo3 fluorescence, reactive oxygen species from 2 ',7'-dichlorodihydrofluorescein-diacetate fluorescence, and ceramide abundance from binding of fluorescent antibodies in flow cytometry. Results: A $48 \mathrm{~h}$ exposure to piperlongumine $(30 \mu \mathrm{M})$ was followed by significant decrease of forward scatter and increase of annexin-V-binding. Piperlongumine did not significantly modify $\left[\mathrm{Ca}^{2+}\right]_{i}$ and the effect was not dependent on presence of extracellular $\mathrm{Ca}^{2+}$. Piperlongumine significantly increased ROS formation and ceramide abundance. Conclusions: Piperlongumine triggers cell membrane scrambling, an effect independent from entry of extracellular $\mathrm{Ca}^{2+}$ but at least partially due to ROS and ceramide formation.
\end{abstract}


Keywords: phosphatidylserine; piperlongumine; calcium; ceramide; cell volume; eryptosis

\section{Introduction}

Piper longum fruit has been and is used for the treatment of multiple disorders including chronic bronchitis, asthma, constipation, gonorrhea, paralysis of the tongue, diarrhea, cholera, chronic malaria, viral hepatitis, respiratory infections, stomachache, bronchitis, diseases of the spleen, cough, and tumors [1]. Piperlongumine (piplartine), an amide alkaloid component of Piper longum fruit [1], has particularly strong cytotoxic activity both, in vitro and in vivo [2-5] and enhances the sensitivity of tumor cells to cytostatic treatment [6]. Piperlongumine is at least partially effective by inducing apoptosis of tumor cells [2,7-14]. Mechanisms involved in the triggering of apoptosis by piperlongumine include induction of oxidative stress $[6,7,9,12,15-17]$. Piperlongumine may bind in tumor cells to the active sites of several key cellular antioxidants including glutathione $\mathrm{S}$ transferase and carbonyl reductase 1 [18]. Beyond that, piperlongumine inhibits PI3K/Akt/mTOR signalling leading to down-regulation of the NF-kB pathway, altered gene expression and activation of the mitochondrial apoptotic pathway $[3,4,8,14,19,20]$. Piperlongumine further activates p38 kinase [15,17], inhibits proteasomal protein degradation [10], and suppresses the transcription factor signal transducer and activator of transcription (STAT) 3 thus modulating expression of multiple Stat3-regulated genes [2].

Similar to apoptosis of nucleated cells, erythrocytes could enter eryptosis, the suicidal erythrocyte death characterized by cell shrinkage and cell membrane scrambling with phosphatidylserine exposure to the erythrocyte surface [21]. Eryptosis could be triggered by increase of cytosolic $\mathrm{Ca}^{2+}$ concentration $\left(\left[\mathrm{Ca}^{2+}\right]_{i}\right)[22]$, ceramide formation [21], caspase activation [23-27], lack of AMP activated kinase AMPK [28], stimulation of casein kinase 1 $\alpha$ [29,30], lack of cGMP-dependent protein kinase [31], stimulation of Janus-activated kinase JAK3 [32], stimulation of protein kinase C [33], stimulation of p38 kinase [34], inhibition of PAK2 kinase [35] as well as inhibition of sorafenib [36] and sunitinib [37] sensitive kinases.

To the best of our knowledge, an effect of piperlongumine on suicidal erythrocyte death has never been reported before. The purpose of the present study was to explore whether piperlongumine triggers eryptosis, i.e., the suicidal death of cells devoid of mitochondria and nuclei. Moreover, the study explored the involvement of $\left[\mathrm{Ca}^{2+}\right]$, ROS formation and ceramide abundance.

\section{Results and Discussion}

The present study explored the putative effect of piperlongumine on eryptosis, the suicidal erythrocyte death. Hallmarks of eryptosis include breakdown of phosphatidylserine asymmetry of the erythrocyte cell membrane with subsequent translocation of phosphatidylserine to the cell surface. Phosphatidylserine exposing erythrocytes were identified by annexin-V-binding in flow cytometry. As illustrated in Figure 1, a $48 \mathrm{~h}$ exposure to piperlongumine increased the percentage of annexin-V-binding erythrocytes, an effect reaching statistical significance at $15 \mu \mathrm{M}$ piperlongumine concentration.

A further hallmark of eryptosis is cell shrinkage. Cell volume was thus estimated from forward scatter in flow cytometry. As shown in Figure 2, a $48 \mathrm{~h}$ exposure to piperlongumine slightly decreased average 
forward scatter, an effect reaching statistical significance at $15 \mu \mathrm{M}$ piperlongumine concentration. Closer inspection of the histogram reveals that the forward scatter decreases substantially in a minor portion of erythrocytes, whereas the forward scatter of most erythrocytes does not appreciably change. Thus, the average forward scatter underestimates the effect of piperlongumine on those erythrocytes which undergo eryptosis.

Figure 1. Effect of piperlongumine on phosphatidylserine exposure (A) Original histogram of annexin $\mathrm{V}$ binding of erythrocytes following exposure for $48 \mathrm{~h}$ to Ringer solution without (grey shadow) and with (black line) presence of $30 \mu \mathrm{M}$ piperlongumine; (B) Arithmetic means \pm SEM $(n=15)$ of erythrocyte annexin-V-binding following incubation for $48 \mathrm{~h}$ to Ringer solution without (white bar) or with (black bars) presence of piperlongumine $(5-30 \mu \mathrm{M})$ or, for comparison, DMSO $(0.1 \%)$ alone. $*(p<0.05), * * *(p<0.001)$ indicate significant differences from the absence of piperlongumine (ANOVA).
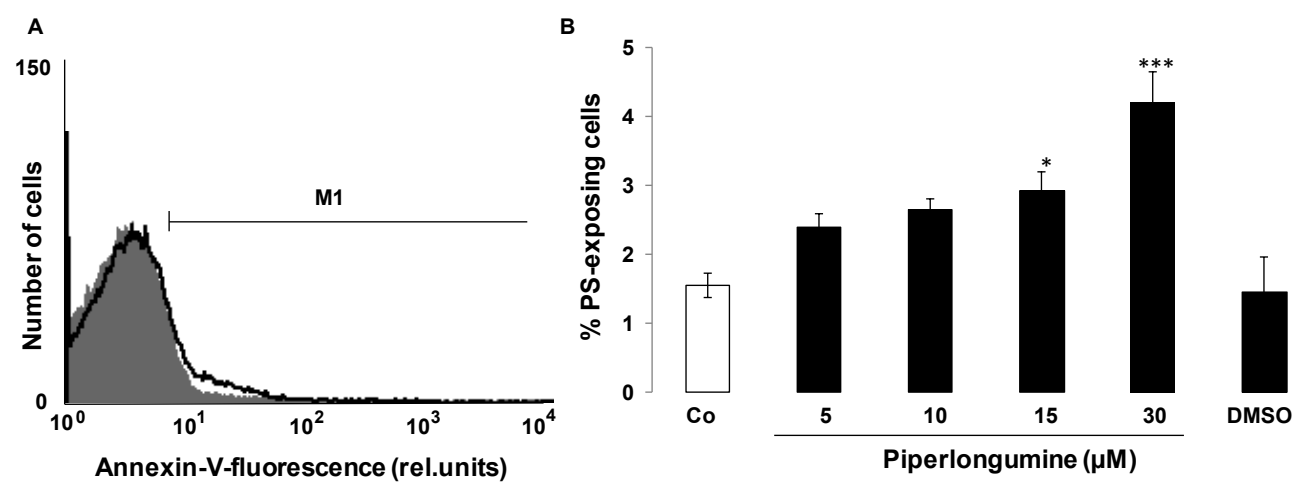

Figure 2. Effect of piperlongumine on erythrocyte forward scatter (A) Original histogram of forward scatter of erythrocytes following exposure for $48 \mathrm{~h}$ to Ringer solution without (grey shadow) and with (black line) presence of $30 \mu \mathrm{M}$ piperlongumine; (B) Arithmetic means $\pm \operatorname{SEM}(n=15)$ of the normalized erythrocyte forward scatter (FSC) following incubation for $48 \mathrm{~h}$ to Ringer solution without (white bar) or with (black bars) piperlongumine $(5-30 \mu \mathrm{M})$ or, for comparison, $\operatorname{DMSO}(0.1 \%)$ alone. $* *(p<0.01), * * *(p<0.001)$ indicate significant differences from the absence of piperlongumine (ANOVA).
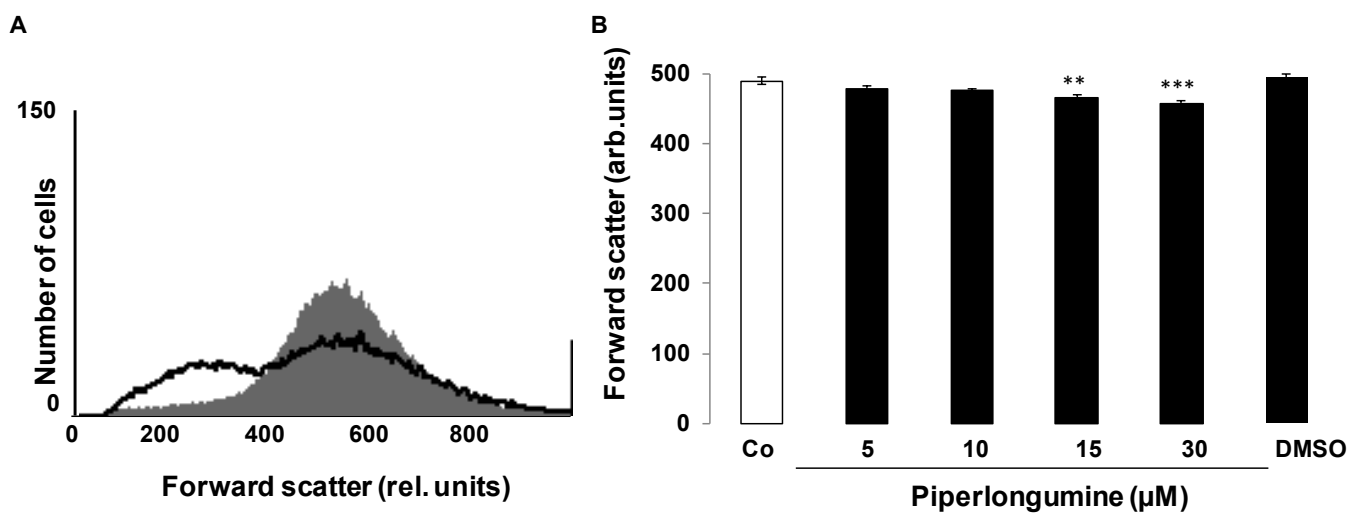

Both, cell membrane scrambling and cell shrinkage could have resulted from increase of cytosolic $\mathrm{Ca}^{2+}$ activity $\left(\left[\mathrm{Ca}^{2+}\right]_{i}\right)$. In order to estimate $\left[\mathrm{Ca}^{2+}\right]$, erythrocytes were loaded with Fluo3-AM and Fluo3 fluorescence determined by flow cytometry. As illustrated in Figure 3A,B, a $48 \mathrm{~h}$ exposure of human 
erythrocytes to piperlongumine tended to slightly increase Fluo3 fluorescence, an effect, however, not reaching statistical significance even at the highest concentration $(30 \mu \mathrm{M})$ employed.

Figure 3. Effect of piperlongumine on erythrocyte cytosolic $\mathrm{Ca}^{2+}$ concentration (A) Original histogram of Fluo3 fluorescence in erythrocytes following exposure for $48 \mathrm{~h}$ to Ringer solution without (grey shadow) and with (black line) presence of $30 \mu \mathrm{M}$ piperlongumine; (B) Arithmetic means $\pm \operatorname{SEM}(n=15)$ of the Fluo3 fluorescence (arbitrary units) in erythrocytes exposed for $48 \mathrm{~h}$ to Ringer solution without (white bar) or with (black bars) piperlongumine $(5-30 \mu \mathrm{M})$ or, for comparison, DMSO $(0.1 \%)$ alone; (C) Arithmetic means $\pm \operatorname{SEM}(n=5)$ of the percentage of annexin-V-binding erythrocytes after a $48 \mathrm{~h}$ treatment with Ringer solution without (white bars) or with (black bars) $30 \mu \mathrm{M}$ piperlongumine in the presence (left bars, +Calcium) and absence (right bars, - Calcium) of calcium. $* * *(p<0.001)$ indicates significant difference from the respective values in the absence of piperlongumine (ANOVA).
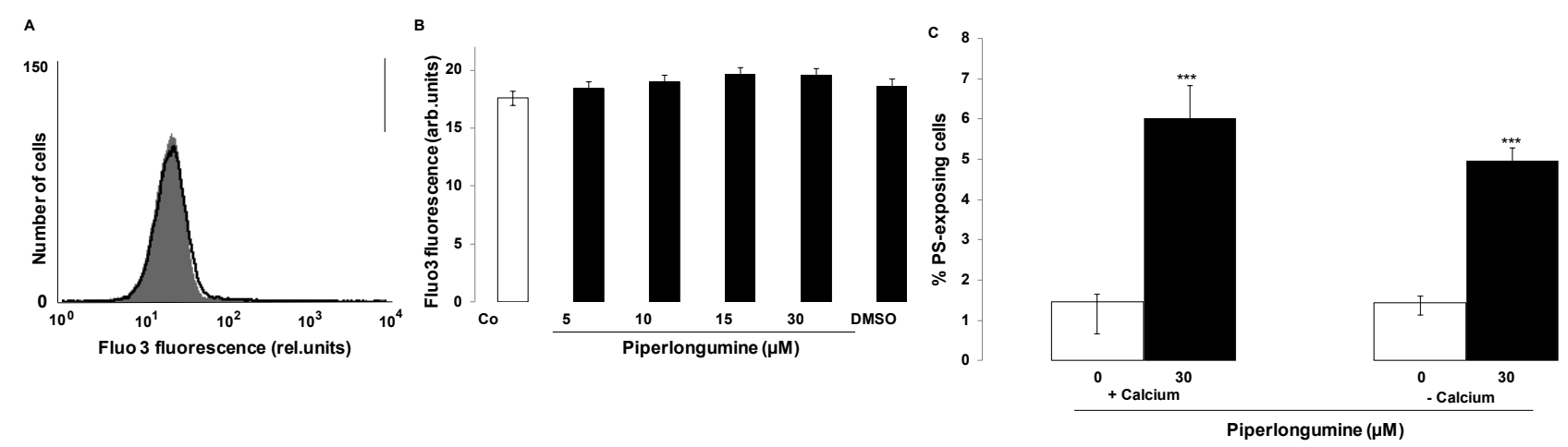

Additional experiments explored, whether the piperlongumine induced cell membrane scrambling required entry of extracellular $\mathrm{Ca}^{2+}$. To this end, erythrocytes were exposed for $48 \mathrm{~h}$ to $30 \mu \mathrm{M}$ piperlongumine in the presence or nominal absence of extracellular $\mathrm{Ca}^{2+}$. As shown in Figure $3 \mathrm{C}$, the effect of piperlongumine on annexin-V-binding tended to be lower in the nominal absence than in the presence of $\mathrm{Ca}^{2+}$, an effect, however, not reaching statistical significance. In the nominal absence of extracellular $\mathrm{Ca}^{2+}$, piperlongumine still significantly increased the percentage of annexin $\mathrm{V}$ binding erythrocytes. Thus, the effect of piperlongumine on cell membrane scrambling did not critically depend on $\mathrm{Ca}^{2+}$ entry.

In order to determine the effect of piperlongumine exposure on hemolysis, the percentage of hemolysed erythrocytes was quantified from hemoglobin concentration in the supernatant. According to the hemoglobin concentration, a $48 \mathrm{~h}$ incubation with $0,5,10,15$ and $30 \mu \mathrm{M}$ piperlongumine resulted in hemolysis of $2.4 \% \pm 0.4 \%, 2.6 \% \pm 0.3 \%, 2.5 \% \pm 0.5 \%, 2.5 \% \pm 0.2 \%$ and $4.6 \% \pm 1.5 \%$ $(n=4)$, respectively.

In search for further mechanisms involved in the effect of piperlongumine on eryptosis, reactive oxygen species (ROS) were determined utilizing 2',7'-dichlorodihydrofluorescein diacetate (DCFDA). As shown in Figure 4, a $48 \mathrm{~h}$ exposure to $30 \mu \mathrm{M}$ piperlongumine markedly and significantly increased the DCFDA fluorescence, a finding pointing to induction of oxidative stress. The percentage of oxidized erythrocytes was higher than the percentage of erythrocytes with translocated phosphatidylserine. Accordingly, strong ROS formation was apparently required to stimulate cell membrane scrambling. 
Figure 4. Effect of piperlongumine on reactive oxygen species (A) Original histogram of 2',7'-dichlorodihydrofluorescein diacetate (DCFDA) fluorescence in erythrocytes following exposure for $48 \mathrm{~h}$ to Ringer solution without (grey shadow) and with (black line) presence of $30 \mu \mathrm{M}$ piperlongumine; (B) Arithmetic means \pm SEM $(n=5)$ of erythrocyte DCFDA fluorescence following incubation for $48 \mathrm{~h}$ to Ringer solution without (white bar) or with (black bar) presence of piperlongumine $(30 \mu \mathrm{M}) . * * *(p<0.001)$ indicates significant difference from the absence of piperlongumine (ANOVA).

A

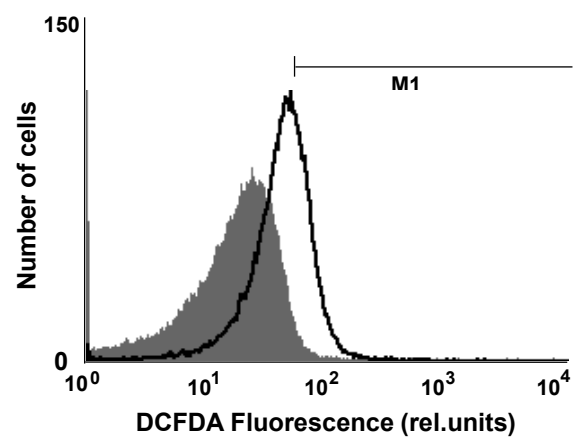

B

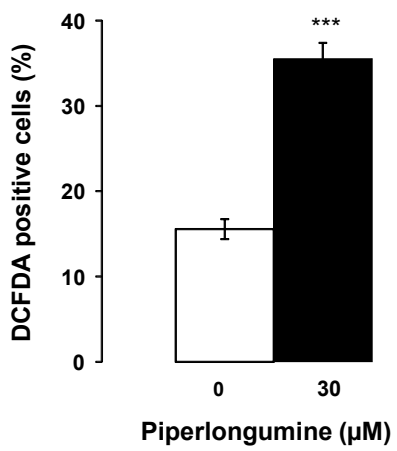

As cell membrane scrambling could be further elicited even at constant $\left[\mathrm{Ca}^{2+}\right]_{\mathrm{i}}$ by ceramide, additional experiments explored, whether piperlongumine increases ceramide formation. The abundance of ceramide at the erythrocyte surface was visualized with an anti-ceramide antibody. As shown in Figure 5, a $48 \mathrm{~h}$ exposure to $30 \mu \mathrm{M}$ piperlongumine significantly increased the ceramide abundance at the erythrocyte surface.

Figure 5. Effect of piperlongumine on ceramide abundance (A) Original histogram of anti-ceramide fluorescein isothiocyanate (FITC) fluorescence in erythrocytes after exposure for $48 \mathrm{~h}$ to Ringer solution without (grey shadow) and with (black line) presence of $30 \mu \mathrm{M}$ piperlongumine; (B) Arithmetic means \pm SEM $(n=9)$ of ceramide abundance at the erythrocyte surface following incubation for $48 \mathrm{~h}$ to Ringer solution without (white bar) or with (black bar) presence of piperlongumine $(30 \mu \mathrm{M}) . * *(p<0.01)$ indicates significant difference from the absence of piperlongumine (ANOVA).
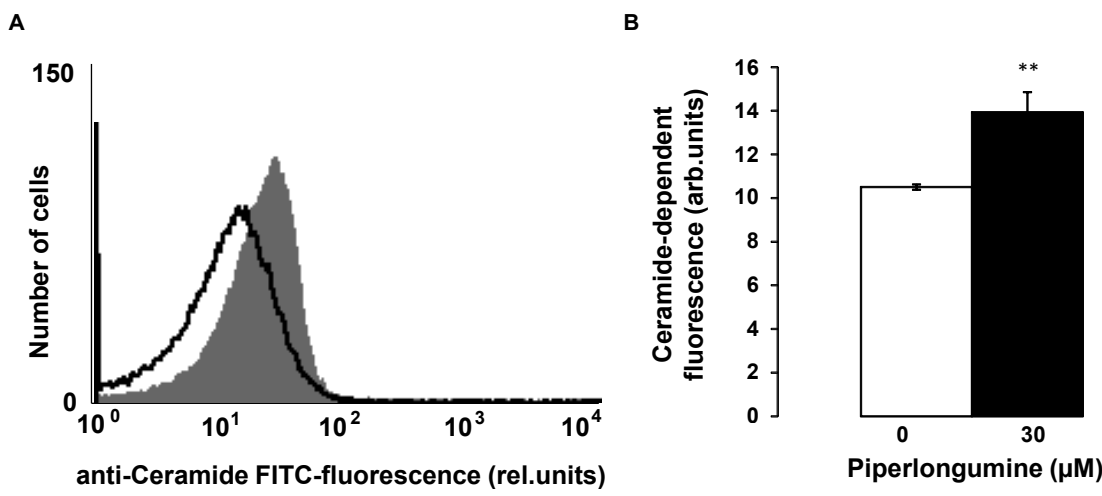

The present study reveals that exposure of human erythrocytes to piperlongumine is followed by eryptosis, the suicidal erythrocyte death characterized by cell shrinkage and cell membrane scrambling with phosphatidylserine translocation to the erythrocyte surface. The piperlongumine concentrations 
required for the triggering of eryptosis are within the range of piperlongumine concentrations employed to elicit apoptosis of tumor cells [20].

Piperlongumine did not significantly increase cytosolic $\mathrm{Ca}^{2+}$ activity $\left(\left[\mathrm{Ca}^{2+}\right]\right.$ ), a major trigger of eryptosis [21]. Instead, piperlongumine increased the abundance of ceramide and induced oxidative stress, both well known triggers of eryptosis [21]. In tumor cells, the apoptotic effect of piperlongumine similarly involves oxidative stress $[6,7,9,12,15-17]$. To the best of our knowledge, an effect of piperlongumine on ceramide formation has never been shown before. It would thus be interesting to learn whether piperlongumine triggers ceramide formation as well in nucleated cells.

The phosphatidylserine exposing erythrocytes attach to respective receptors of phagocytes with subsequent engulfment and degradation of the defective erythrocytes [21]. Thus, eryptotic phosphatidylserine exposing erythrocytes are rapidly cleared from circulating blood [21]. The eryptotic cell shrinkage [22] counteracts swelling of the defective cells, which would otherwise lead to rupture of the cell membrane with release of cellular hemoglobin. Released hemoglobin may be filtered in renal glomeruli, subsequently precipitate in the acidic lumen of renal tubules and thus occlude the tubules [38].

Excessive eryptosis may become pathophysiologically relevant. The clearance of phosphatidylserine exposing erythrocytes from circulating blood may lead to anemia as soon as the loss of eryptotic erythrocytes fails to be outweighed by similar formation of new erythrocytes [21]. Treatment of erythrocytes with 15 or $30 \mu \mathrm{M}$ piperlongumine approximately doubles the percentage of phosphatidylserine exposing erythrocytes. In the absence of compensatory increase of erythropoiesis, the effect would halve the number of erythrocytes in circulating blood and thus lead to severe anemia. Phosphatidylserine exposing erythrocytes may further adhere to endothelial receptors [39]. The attachment of eryptotic erythrocytes to the vascular wall compromises microcirculation [39-44]. Moreover, phosphatidylserine exposing erythrocytes stimulate blood clotting and thus thrombosis $[40,45,46]$.

The sensitivity of erythrocytes to piperlongumine may be augmented by additional exposure to further eryptosis triggering xenobiotics $[21,37,47-80]$ or in patients suffering from disorders facilitating eryptosis [21], such as diabetes [27,81,82], renal insufficiency [83], hemolytic uremic syndrome [84], sepsis [85], malaria [86], sickle cell disease [86], Wilson's disease [87], iron deficiency [88], malignancy [89], phosphate depletion [90], and metabolic syndrome [65].

\section{Experimental Section}

\subsection{Erythrocytes, Solutions and Chemicals}

Fresh Li-Heparin-anticoagulated blood samples were kindly provided by the blood bank of the University of Tübingen. The study is approved by the ethics committee of the University of Tübingen (184/2003V). The blood was centrifuged at $120 \mathrm{rcf}$ for $20 \mathrm{~min}$ at $23{ }^{\circ} \mathrm{C}$ and the platelets and leukocytes-containing supernatant were disposed. Erythrocytes were washed in Ringer solution containing (in $\mathrm{mM}$ ) $125 \mathrm{NaCl}, 5 \mathrm{KCl}, 1 \mathrm{MgSO} 4,32 \mathrm{~N}$-2-hydroxyethylpiperazine- $N$-2-ethanesulfonic acid (HEPES, $\mathrm{pH}$ 7.4), 5 glucose, and $1 \mathrm{CaCl}_{2}$. For the experiments, erythrocytes were incubated in vitro at a hematocrit of $0.4 \%$ at $37^{\circ} \mathrm{C}$ for $48 \mathrm{~h}$. Where indicated, erythrocytes were exposed to piperlongumine (Sigma-Aldrich, Hamburg, Germany) at the indicated concentrations. In $\mathrm{Ca}^{2+}$-free Ringer solution, $1 \mathrm{mM} \mathrm{CaCl} 2$ was substituted by $1 \mathrm{mM}$ glycol-bis(2-aminoethylether)- $N, N, N^{\prime}, N^{\prime}$-tetraacetic acid (EGTA). 


\subsection{FACS Analysis of Annexin-V-Binding and Forward Scatter}

After incubation under the respective experimental condition, $50 \mu \mathrm{L}$ cell suspension was washed in Ringer solution containing $5 \mathrm{mM} \mathrm{CaCl}_{2}$ and then stained with Annexin-V-FITC (1:200 dilution; ImmunoTools, Friesoythe, Germany) in this solution at $37{ }^{\circ} \mathrm{C}$ for 20 min under protection from light. In the following, the forward scatter (FSC) of the cells was determined, and annexin-V fluorescence intensity was measured with an excitation wavelength of $488 \mathrm{~nm}$ and an emission wavelength of $530 \mathrm{~nm}$ on a FACS Calibur (BD, Heidelberg, Germany).

\subsection{Measurement of Intracellular $\mathrm{Ca}^{2+}$}

After incubation, erythrocytes were washed in Ringer solution and then loaded with Fluo-3/AM (Biotium, Hayward, CA, USA) in Ringer solution containing $5 \mathrm{mM} \mathrm{CaCl}_{2}$ and $5 \mu \mathrm{M}$ Fluo-3/AM. The cells were incubated at $37{ }^{\circ} \mathrm{C}$ for $30 \mathrm{~min}$ and washed twice in Ringer solution containing $5 \mathrm{mM} \mathrm{CaCl}$. The Fluo-3/AM-loaded erythrocytes were resuspended in $200 \mu \mathrm{L}$ Ringer. Then, $\mathrm{Ca}^{2+}$-dependent fluorescence intensity was measured with an excitation wavelength of $488 \mathrm{~nm}$ and an emission wavelength of $530 \mathrm{~nm}$ on a FACS Calibur. The adequacy of Fluo-3 fluorescence as a tool to estimate cytosolic $\mathrm{Ca}^{2+}$ activity has been tested in several previous studies [29,91-94].

\subsection{Determination of ROS Production}

ROS production was determined utilizing 2',7'-dichlorodihydrofluorescein diacetate (DCFDA) [95]. Briefly, the cells were suspended in FACS buffer and the fluorescence was analysed with flow cytometry (FACS-calibur from Becton Dickinson; Heidelberg, Germany). DCFDA fluorescence intensity was measured in FL-1 with an excitation wavelength of $488 \mathrm{~nm}$ and an emission wavelength of $530 \mathrm{~nm}$.

\subsection{Determination of Ceramide Formation}

For the determination of ceramide, a monoclonal antibody-based assay was used. After incubation, cells were stained for $1 \mathrm{~h}$ at $37^{\circ} \mathrm{C}$ with $1 \mu \mathrm{g} / \mathrm{mL}$ anti ceramide antibody (clone MID 15B4, Alexis, Grünberg, Germany) in PBS containing 0.1\% bovine serum albumin (BSA) at a dilution of 1:10. The samples were washed twice with PBS-BSA. Subsequently, the cells were stained for 30 min with polyclonal fluorescein isothiocyanate (FITC) conjugated goat anti-mouse IgG and IgM specific antibody (Pharmingen, Hamburg, Germany) diluted 1:50 in PBS-BSA. Unbound secondary antibody was removed by repeated washing with PBS-BSA. The samples were then analyzed by flow cytometric analysis with an excitation wavelength of $488 \mathrm{~nm}$ and an emission wavelength of $530 \mathrm{~nm}$.

\subsection{Measurement of Hemolysis}

For the determination of hemolysis, the samples were centrifuged ( 3 min at 1600 RPM, room temperature) after incubation, and the supernatants were harvested. As a measure of hemolysis, the hemoglobin $(\mathrm{Hb})$ concentration of the supernatant was determined photometrically at $405 \mathrm{~nm}$. The absorption of the supernatant of erythrocytes lysed in distilled water was defined as $100 \%$ hemolysis. 


\subsection{Statistics}

Data are expressed as arithmetic means \pm SEM. As indicated in the figure legends, statistical analysis was made using ANOVA with Tukey's test as post-test and $t$ test as appropriate. The number of different erythrocyte specimens studied is given as $\mathrm{n}$. Since different erythrocyte specimens used in distinct experiments are differently susceptible to triggers of eryptosis, the same erythrocyte specimens have been used for control and experimental conditions.

\section{Conclusions}

In conclusion, the present paper unequivocally and significantly demonstrates that piperlongumine stimulates eryptosis with erythrocyte shrinkage and cell membrane scrambling. Thus, piperlongumine is able to trigger suicidal death in cells lacking mitochondria and nuclei. The cellular mechanisms involved include oxidative stress and ceramide formation. To the best of our knowledge, an effect of piperlongumine on suicidal erythrocyte death or of ceramide formation in any cell type has never been reported before.

\section{Acknowledgments}

The authors acknowledge the meticulous preparation of the manuscript by Tanja Loch. The study was supported by the Deutsche Forschungsgemeinschaft and the Open Access Publishing Fund of Tuebingen University.

\section{Author Contributions}

Rosi Bissinger, Abaid Malik and Jamshed Warsi performed the experiments. Rosi Bissinger executed the statistical analysis. Kashif Jilani supervised the study and prepared the figures. Florian Lang designed the study and drafted the manuscript. All authors carefully read and approved the manuscript.

\section{Conflicts of Interest}

The authors declare no conflict of interest.

\section{References}

1. Kumar, S.; Kamboj, J.; Suman; Sharma, S. Overview for various aspects of the health benefits of piper longum linn. Fruit. J. Acupunct. Meridian Stud. 2011, 4, 134-140.

2. Bharadwaj, U.; Eckols, T.K.; Kolosov, M.; Kasembeli, M.M.; Adam, A.; Torres, D.; Zhang, X.; Dobrolecki, L.E.; Wei, W.; Lewis, M.T.; et al. Drug-repositioning screening identified piperlongumine as a direct stat 3 inhibitor with potent activity against breast cancer. Oncogene 2014, doi:10.1038/onc.2014.72.

3. Makhov, P.; Golovine, K.; Teper, E.; Kutikov, A.; Mehrazin, R.; Corcoran, A.; Tulin, A.; Uzzo, R.G.; Kolenko, V.M. Piperlongumine promotes autophagy via inhibition of akt/mtor signalling and mediates cancer cell death. Br. J. Cancer 2014, 110, 899-907. 
4. Shrivastava, S.; Kulkarni, P.; Thummuri, D.; Jeengar, M.K.; Naidu, V.G.; Alvala, M.; Redddy, G.B.; Ramakrishna, S. Piperlongumine, an alkaloid causes inhibition of pi3 k/akt/mtor signaling axis to induce caspase-dependent apoptosis in human triple-negative breast cancer cells. Apoptosis 2014, 19, 1148-1164.

5. Wang, Y.H.; Morris-Natschke, S.L.; Yang, J.; Niu, H.M.; Long, C.L.; Lee, K.H. Anticancer principles from medicinal (hu jiao) plants. J. Tradit. Complement. Med. 2014, 4, 8-16.

6. Yao, J.X.; Yao, Z.F.; Li, Z.F.; Liu, Y.B. Radio-sensitization by piper longumine of human breast adenoma mda-mb-231 cells in vitro. Asian Pac. J. Cancer Prev. 2014, 15, 3211-3217.

7. Adams, D.J.; Dai, M.; Pellegrino, G.; Wagner, B.K.; Stern, A.M.; Shamji, A.F.; Schreiber, S.L. Synthesis, cellular evaluation, and mechanism of action of piperlongumine analogs. Proc. Natl. Acad. Sci. USA 2012, 109, 15115-15120.

8. Farrand, L.; Kim, J.Y.; Im-Aram, A.; Suh, J.Y.; Lee, H.J.; Tsang, B.K. An improved quantitative approach for the assessment of mitochondrial fragmentation in chemoresistant ovarian cancer cells. PLoS One 2013, 8, e74008.

9. Gong, L.H.; Chen, X.X.; Wang, H.; Jiang, Q.W.; Pan, S.S.; Qiu, J.G.; Mei, X.L.; Xue, Y.Q.; Qin, W.M.; Zheng, F.Y.; et al. Piperlongumine induces apoptosis and synergizes with cisplatin or paclitaxel in human ovarian cancer cells. Oxid. Med. Cell. Longev. 2014, 2014, 906804, doi:10.1155/2014/906804.

10. Halasi, M.; Wang, M.; Chavan, T.S.; Gaponenko, V.; Hay, N.; Gartel, A.L. Ros inhibitor n-acetyl-1-cysteine antagonizes the activity of proteasome inhibitors. Biochem. J. 2013, 454, 201-208.

11. Maund, S.L.; Nolley, R.; Peehl, D.M. Optimization and comprehensive characterization of a faithful tissue culture model of the benign and malignant human prostate. Lab. Investig. 2014, 94, 208-221.

12. Raj, L.; Ide, T.; Gurkar, A.U.; Foley, M.; Schenone, M.; Li, X.; Tolliday, N.J.; Golub, T.R.; Carr, S.A.; Shamji, A.F.; et al. Selective killing of cancer cells by a small molecule targeting the stress response to ros. Nature 2011, 475, 231-234.

13. Tomasini-Johansson, B.R.; Johnson, I.A.; Hoffmann, F.M.; Mosher, D.F. Quantitative microtiter fibronectin fibrillogenesis assay: Use in high throughput screening for identification of inhibitor compounds. Matrix Biol. 2012, 31, 360-367.

14. Han, S.S.; Tompkins, V.S.; Son, D.J.; Kamberos, N.L.; Stunz, L.L.; Halwani, A.; Bishop, G.A.; Janz, S. Piperlongumine inhibits $1 \mathrm{mp} 1 /$ myc-dependent mouse b-lymphoma cells. Biochem. Biophys. Res. Commun. 2013, 436, 660-665.

15. Liu, J.M.; Pan, F.; Li, L.; Liu, Q.R.; Chen, Y.; Xiong, X.X.; Cheng, K.; Yu, S.B.; Shi, Z.; $\mathrm{Yu}$, A.C.; et al. Piperlongumine selectively kills glioblastoma multiforme cells via reactive oxygen species accumulation dependent jnk and p38 activation. Biochem. Biophys. Res. Commun. 2013, 437, 87-93.

16. Randhawa, H.; Kibble, K.; Zeng, H.; Moyer, M.P.; Reindl, K.M. Activation of erk signaling and induction of colon cancer cell death by piperlongumine. Toxicol. In Vitro 2013, 27, 1626-1633.

17. Wang, Y.; Wang, J.W.; Xiao, X.; Shan, Y.; Xue, B.; Jiang, G.; He, Q.; Chen, J.; Xu, H.G.; Zhao, R.X.; et al. Piperlongumine induces autophagy by targeting p38 signaling. Cell Death Dis. 2013, 4, e824, doi:10.1038/cddis.2013.358. 
18. Saeidnia, S.; Abdollahi, M. Antioxidants: Friends or foe in prevention or treatment of cancer: The debate of the century. Toxicol. Appl. Pharmacol. 2013, 271, 49-63.

19. Ginzburg, S.; Golovine, K.V.; Makhov, P.B.; Uzzo, R.G.; Kutikov, A.; Kolenko, V.M. Piperlongumine inhibits nf-kappab activity and attenuates aggressive growth characteristics of prostate cancer cells. Prostate 2014, 74, 177-186.

20. Han, S.S.; Son, D.J.; Yun, H.; Kamberos, N.L.; Janz, S. Piperlongumine inhibits proliferation and survival of burkitt lymphoma in vitro. Leuk. Res. 2013, 37, 146-154.

21. Lang, E.; Qadri, S.M.; Lang, F. Killing me softly-Suicidal erythrocyte death. Int. J. Biochem. Cell Biol. 2012, 44, 1236-1243.

22. Lang, P.A.; Kaiser, S.; Myssina, S.; Wieder, T.; Lang, F.; Huber, S.M. Role of $\mathrm{Ca}^{2+}$-activated k+ channels in human erythrocyte apoptosis. Am. J. Physiol. Cell Physiol. 2003, 285, C1553-C1560.

23. Bhavsar, S.K.; Bobbala, D.; Xuan, N.T.; Foller, M.; Lang, F. Stimulation of suicidal erythrocyte death by alpha-lipoic acid. Cell. Physiol. Biochem. 2010, 26, 859-868.

24. Foller, M.; Huber, S.M.; Lang, F. Erythrocyte programmed cell death. IUBMB Life 2008, 60, 661-668.

25. Foller, M.; Mahmud, H.; Gu, S.; Wang, K.; Floride, E.; Kucherenko, Y.; Luik, S.; Laufer, S.; Lang, F. Participation of leukotriene $\mathrm{c}(4)$ in the regulation of suicidal erythrocyte death. J. Physiol. Pharmacol. 2009, 60, 135-143.

26. Lau, I.P.; Chen, H.; Wang, J.; Ong, H.C.; Leung, K.C.; Ho, H.P.; Kong, S.K. In vitro effect of ctab- and peg-coated gold nanorods on the induction of eryptosis/erythroptosis in human erythrocytes. Nanotoxicology 2012, 6, 847-856.

27. Maellaro, E.; Leoncini, S.; Moretti, D.; del Bello, B.; Tanganelli, I.; de Felice, C.; Ciccoli, L. Erythrocyte caspase-3 activation and oxidative imbalance in erythrocytes and in plasma of type 2 diabetic patients. Acta Diabetol. 2013, 50, 489-495.

28. Foller, M.; Sopjani, M.; Koka, S.; Gu, S.; Mahmud, H.; Wang, K.; Floride, E.; Schleicher, E.; Schulz, E.; Munzel, T.; et al. Regulation of erythrocyte survival by amp-activated protein kinase. FASEB J. 2009, 23, 1072-1080.

29. Kucherenko, Y.; Zelenak, C.; Eberhard, M.; Qadri, S.M.; Lang, F. Effect of casein kinase 1alpha activator pyrvinium pamoate on erythrocyte ion channels. Cell. Physiol. Biochem. 2012, 30, 407-417.

30. Zelenak, C.; Eberhard, M.; Jilani, K.; Qadri, S.M.; Macek, B.; Lang, F. Protein kinase ck1alpha regulates erythrocyte survival. Cell. Physiol. Biochem. 2012, 29, 171-180.

31. Foller, M.; Feil, S.; Ghoreschi, K.; Koka, S.; Gerling, A.; Thunemann, M.; Hofmann, F.; Schuler, B.; Vogel, J.; Pichler, B.; et al. Anemia and splenomegaly in cgki-deficient mice. Proc. Natl. Acad. Sci. USA 2008, 105, 6771-6776.

32. Bhavsar, S.K.; Gu, S.; Bobbala, D.; Lang, F. Janus kinase 3 is expressed in erythrocytes, phosphorylated upon energy depletion and involved in the regulation of suicidal erythrocyte death. Cell. Physiol. Biochem. 2011, 27, 547-556.

33. Klarl, B.A.; Lang, P.A.; Kempe, D.S.; Niemoeller, O.M.; Akel, A.; Sobiesiak, M.; Eisele, K.; Podolski, M.; Huber, S.M.; Wieder, T.; et al. Protein kinase c mediates erythrocyte "programmed cell death" following glucose depletion. Am. J. Physiol. Cell Physiol. 2006, 290, C244-C253. 
34. Gatidis, S.; Zelenak, C.; Fajol, A.; Lang, E.; Jilani, K.; Michael, D.; Qadri, S.M.; Lang, F. P38 mapk activation and function following osmotic shock of erythrocytes. Cell. Physiol. Biochem. 2011, 28, 1279-1286.

35. Zelenak, C.; Foller, M.; Velic, A.; Krug, K.; Qadri, S.M.; Viollet, B.; Lang, F.; Macek, B. Proteome analysis of erythrocytes lacking amp-activated protein kinase reveals a role of pak2 kinase in eryptosis. J. Proteome Res. 2011, 10, 1690-1697.

36. Lupescu, A.; Shaik, N.; Jilani, K.; Zelenak, C.; Lang, E.; Pasham, V.; Zbidah, M.; Plate, A.; Bitzer, M.; Foller, M.; et al. Enhanced erythrocyte membrane exposure of phosphatidylserine following sorafenib treatment: An in vivo and in vitro study. Cell. Physiol. Biochem. 2012, 30, 876-888.

37. Shaik, N.; Lupescu, A.; Lang, F. Sunitinib-sensitive suicidal erythrocyte death. Cell. Physiol. Biochem. 2012, 30, 512-522.

38. Harrison, H.E.; Bunting, H.; Ordway, N.K.; Albrink, W.S. The pathogenesis of the renal injury produced in the dog by hemoglobin or methemoglobin. J. Exp. Med. 1947, 86, 339-356.

39. Borst, O.; Abed, M.; Alesutan, I.; Towhid, S.T.; Qadri, S.M.; Foller, M.; Gawaz, M.; Lang, F. Dynamic adhesion of eryptotic erythrocytes to endothelial cells via cxcl16/sr-psox. Am. J. Physiol. Cell Physiol. 2012, 302, C644-C651.

40. Andrews, D.A.; Low, P.S. Role of red blood cells in thrombosis. Curr. Opin. Hematol. 1999, 6, $76-82$.

41. Closse, C.; Dachary-Prigent, J.; Boisseau, M.R. Phosphatidylserine-related adhesion of human erythrocytes to vascular endothelium. Br. J. Haematol. 1999, 107, 300-302.

42. Gallagher, P.G.; Chang, S.H.; Rettig, M.P.; Neely, J.E.; Hillery, C.A.; Smith, B.D.; Low, P.S. Altered erythrocyte endothelial adherence and membrane phospholipid asymmetry in hereditary hydrocytosis. Blood 2003, 101, 4625-4627.

43. Pandolfi, A.; di Pietro, N.; Sirolli, V.; Giardinelli, A.; di Silvestre, S.; Amoroso, L.; di Tomo, P.; Capani, F.; Consoli, A.; Bonomini, M. Mechanisms of uremic erythrocyte-induced adhesion of human monocytes to cultured endothelial cells. J. Cell. Physiol. 2007, 213, 699-709.

44. Wood, B.L.; Gibson, D.F.; Tait, J.F. Increased erythrocyte phosphatidylserine exposure in sickle cell disease: Flow-cytometric measurement and clinical associations. Blood 1996, 88, 1873-1880.

45. Chung, S.M.; Bae, O.N.; Lim, K.M.; Noh, J.Y.; Lee, M.Y.; Jung, Y.S.; Chung, J.H. Lysophosphatidic acid induces thrombogenic activity through phosphatidylserine exposure and procoagulant microvesicle generation in human erythrocytes. Arterioscler. Thromb. Vasc. Biol. 2007, 27, 414-421.

46. Zwaal, R.F.; Comfurius, P.; Bevers, E.M. Surface exposure of phosphatidylserine in pathological cells. Cell. Mol. Life Sci. 2005, 62, 971-988.

47. Abed, M.; Towhid, S.T.; Mia, S.; Pakladok, T.; Alesutan, I.; Borst, O.; Gawaz, M.; Gulbins, E.; Lang, F. Sphingomyelinase-induced adhesion of eryptotic erythrocytes to endothelial cells. Am. J. Physiol. Cell Physiol. 2012, 303, C991-C999.

48. Bottger, E.; Multhoff, G.; Kun, J.F.; Esen, M. Plasmodium falciparum-infected erythrocytes induce granzyme b by nk cells through expression of host-hsp70. PLoS One 2012, 7, e33774.

49. Firat, U.; Kaya, S.; Cim, A.; Buyukbayram, H.; Gokalp, O.; Dal, M.S.; Tamer, M.N. Increased caspase-3 immunoreactivity of erythrocytes in stz diabetic rats. Exp. Diabetes Res. 2012, 2012, 316384, doi:10.1155/2012/316384. 
50. Ganesan, S.; Chaurasiya, N.D.; Sahu, R.; Walker, L.A.; Tekwani, B.L. Understanding the mechanisms for metabolism-linked hemolytic toxicity of primaquine against glucose 6-phosphate dehydrogenase deficient human erythrocytes: Evaluation of eryptotic pathway. Toxicology 2012, 294, 54-60.

51. Gao, M.; Cheung, K.L.; Lau, I.P.; Yu, W.S.; Fung, K.P.; Yu, B.; Loo, J.F.; Kong, S.K. Polyphyllin $\mathrm{d}$ induces apoptosis in human erythrocytes through $\mathrm{ca}(2)(+)$ rise and membrane permeabilization. Arch. Toxicol. 2012, 86, 741-752.

52. Ghashghaeinia, M.; Cluitmans, J.C.; Akel, A.; Dreischer, P.; Toulany, M.; Koberle, M.; Skabytska, Y.; Saki, M.; Biedermann, T.; Duszenko, M.; et al. The impact of erythrocyte age on eryptosis. Br. J. Haematol. 2012, 157, 606-614.

53. Jilani, K.; Lupescu, A.; Zbidah, M.; Abed, M.; Shaik, N.; Lang, F. Enhanced apoptotic death of erythrocytes induced by the mycotoxin ochratoxin A. Kidney Blood Press. Res. 2012, 36, 107-118.

54. Jilani, K.; Lupescu, A.; Zbidah, M.; Shaik, N.; Lang, F. Withaferin a-stimulated $\mathrm{Ca}^{2+}$ entry, ceramide formation and suicidal death of erythrocytes. Toxicol. In Vitro 2013, 27, 52-58.

55. Kucherenko, Y.V.; Lang, F. Inhibitory effect of furosemide on non-selective voltage-independent cation channels in human erythrocytes. Cell. Physiol. Biochem. 2012, 30, 863-875.

56. Lang, E.; Jilani, K.; Zelenak, C.; Pasham, V.; Bobbala, D.; Qadri, S.M.; Lang, F. Stimulation of suicidal erythrocyte death by benzethonium. Cell. Physiol. Biochem. 2011, 28, 347-354.

57. Lang, E.; Qadri, S.M.; Jilani, K.; Zelenak, C.; Lupescu, A.; Schleicher, E.; Lang, F. Carbon monoxide-sensitive apoptotic death of erythrocytes. Basic Clin. Pharmacol. Toxicol. 2012, 111, 348-355.

58. Lupescu, A.; Jilani, K.; Zbidah, M.; Lang, E.; Lang, F. Enhanced ca(2+) entry, ceramide formation, and apoptotic death of erythrocytes triggered by plumbagin. J. Nat. Prod. 2012, 75, 1956-1961.

59. Lupescu, A.; Jilani, K.; Zbidah, M.; Lang, F. Induction of apoptotic erythrocyte death by rotenone. Toxicology 2012, 300, 132-137.

60. Polak-Jonkisz, D.; Purzyc, L. Ca influx vs. efflux during eryptosis in uremic erythrocytes. Blood Purif. 2012, 34, 209-210.

61. Qian, E.W.; Ge, D.T.; Kong, S.K. Salidroside protects human erythrocytes against hydrogen peroxide-induced apoptosis. J. Nat. Prod. 2012, 75, 531-537.

62. Shaik, N.; Zbidah, M.; Lang, F. Inhibition of ca(2+) entry and suicidal erythrocyte death by naringin. Cell. Physiol. Biochem. 2012, 30, 678-686.

63. Vota, D.M.; Maltaneri, R.E.; Wenker, S.D.; Nesse, A.B.; Vittori, D.C. Differential erythropoietin action upon cells induced to eryptosis by different agents. Cell Biochem. Biophys. 2013, 65, 145-157.

64. Weiss, E.; Cytlak, U.M.; Rees, D.C.; Osei, A.; Gibson, J.S. Deoxygenation-induced and Ca(2+) dependent phosphatidylserine externalisation in red blood cells from normal individuals and sickle cell patients. Cell Calcium 2012, 51, 51-56.

65. Zappulla, D. Environmental stress, erythrocyte dysfunctions, inflammation, and the metabolic syndrome: Adaptations to co2 increases? J. Cardiometab. Syndr. 2008, 3, 30-34.

66. Zbidah, M.; Lupescu, A.; Jilani, K.; Lang, F. Stimulation of suicidal erythrocyte death by fumagillin. Basic Clin. Pharmacol. Toxicol. 2013, 112, 346-351. 
67. Zbidah, M.; Lupescu, A.; Shaik, N.; Lang, F. Gossypol-induced suicidal erythrocyte death. Toxicology 2012, 302, 101-105.

68. Zelenak, C.; Pasham, V.; Jilani, K.; Tripodi, P.M.; Rosaclerio, L.; Pathare, G.; Lupescu, A.; Faggio, C.; Qadri, S.M.; Lang, F. Tanshinone iia stimulates erythrocyte phosphatidylserine exposure. Cell. Physiol. Biochem. 2012, 30, 282-294.

69. Abed, M.; Herrmann, T.; Alzoubi, K.; Pakladok, T.; Lang, F. Tannic acid induced suicidal erythrocyte death. Cell. Physiol. Biochem. 2013, 32, 1106-1116.

70. Ahmed, M.S.; Langer, H.; Abed, M.; Voelkl, J.; Lang, F. The uremic toxin acrolein promotes suicidal erythrocyte death. Kidney Blood Press. Res. 2013, 37, 158-167.

71. Ghashghaeinia, M.; Cluitmans, J.C.; Toulany, M.; Saki, M.; Koberle, M.; Lang, E.; Dreischer, P.; Biedermann, T.; Duszenko, M.; Lang, F.; et al. Age sensitivity of nfkappab abundance and programmed cell death in erythrocytes induced by nfkappab inhibitors. Cell. Physiol. Biochem. 2013, 32, 801-813.

72. Lupescu, A.; Jilani, K.; Zbidah, M.; Lang, F. Patulin-induced suicidal erythrocyte death. Cell. Physiol. Biochem. 2013, 32, 291-299.

73. Alzoubi, K.; Alktifan, B.; Oswald, G.; Fezai, M.; Abed, M.; Lang, F. Breakdown of phosphatidylserine asymmetry following treatment of erythrocytes with lumefantrine. Toxins (Basel) 2014, 6, 650-664.

74. Alzoubi, K.; Honisch, S.; Abed, M.; Lang, F. Triggering of suicidal erythrocyte death by penta-O-galloyl-beta-D-glucose. Toxins (Basel) 2014, 6, 54-65.

75. Frauenfeld, L.; Alzoubi, K.; Abed, M.; Lang, F. Stimulation of erythrocyte cell membrane scrambling by mushroom tyrosinase. Toxins (Basel) 2014, 6, 1096-1108.

76. Jilani, K.; Enkel, S.; Bissinger, R.; Almilaji, A.; Abed, M.; Lang, F. Fluoxetine induced suicidal erythrocyte death. Toxins (Basel) 2013, 5, 1230-1243.

77. Jilani, K.; Lang, F. Carmustine-induced phosphatidylserine translocation in the erythrocyte membrane. Toxins (Basel) 2013, 5, 703-716.

78. Lang, E.; Modicano, P.; Arnold, M.; Bissinger, R.; Faggio, C.; Abed, M.; Lang, F. Effect of thioridazine on erythrocytes. Toxins (Basel) 2013, 5, 1918-1931.

79. Lupescu, A.; Bissinger, R.; Jilani, K.; Lang, F. Triggering of suicidal erythrocyte death by celecoxib. Toxins (Basel) 2013, 5, 1543-1554.

80. Lupescu, A.; Bissinger, R.; Jilani, K.; Lang, F. In vitro induction of erythrocyte phosphatidylserine translocation by the natural naphthoquinone shikonin. Toxins (Basel) 2014, 6, 1559-1574.

81. Calderon-Salinas, J.V.; Munoz-Reyes, E.G.; Guerrero-Romero, J.F.; Rodriguez-Moran, M.; Bracho-Riquelme, R.L.; Carrera-Gracia, M.A.; Quintanar-Escorza, M.A. Eryptosis and oxidative damage in type 2 diabetic mellitus patients with chronic kidney disease. Mol. Cell Biochem. 2011, 357, 171-179.

82. Nicolay, J.P.; Schneider, J.; Niemoeller, O.M.; Artunc, F.; Portero-Otin, M.; Haik, G., Jr.; Thornalley, P.J.; Schleicher, E.; Wieder, T.; Lang, F. Stimulation of suicidal erythrocyte death by methylglyoxal. Cell. Physiol. Biochem. 2006, 18, 223-232.

83. Myssina, S.; Huber, S.M.; Birka, C.; Lang, P.A.; Lang, K.S.; Friedrich, B.; Risler, T.; Wieder, T.; Lang, F. Inhibition of erythrocyte cation channels by erythropoietin. J. Am. Soc. Nephrol. 2003, 14, 2750-2757. 
84. Lang, P.A.; Beringer, O.; Nicolay, J.P.; Amon, O.; Kempe, D.S.; Hermle, T.; Attanasio, P.; Akel, A.; Schafer, R.; Friedrich, B.; et al. Suicidal death of erythrocytes in recurrent hemolytic uremic syndrome. J. Mol. Med. (Berl.) 2006, 84, 378-388.

85. Kempe, D.S.; Akel, A.; Lang, P.A.; Hermle, T.; Biswas, R.; Muresanu, J.; Friedrich, B.; Dreischer, P.; Wolz, C.; Schumacher, U.; et al. Suicidal erythrocyte death in sepsis. J. Mol. Med. 2007, 85, 269-277.

86. Foller, M.; Bobbala, D.; Koka, S.; Huber, S.M.; Gulbins, E.; Lang, F. Suicide for survival—Death of infected erythrocytes as a host mechanism to survive malaria. Cell. Physiol. Biochem. 2009, 24, 133-140.

87. Lang, P.A.; Schenck, M.; Nicolay, J.P.; Becker, J.U.; Kempe, D.S.; Lupescu, A.; Koka, S.; Eisele, K.; Klarl, B.A.; Rubben, H.; et al. Liver cell death and anemia in wilson disease involve acid sphingomyelinase and ceramide. Nat. Med. 2007, 13, 164-170.

88. Kempe, D.S.; Lang, P.A.; Duranton, C.; Akel, A.; Lang, K.S.; Huber, S.M.; Wieder, T.; Lang, F. Enhanced programmed cell death of iron-deficient erythrocytes. FASEB J. 2006, 20, 368-370.

89. Qadri, S.M.; Mahmud, H.; Lang, E.; Gu, S.; Bobbala, D.; Zelenak, C.; Jilani, K.; Siegfried, A.; Foller, M.; Lang, F. Enhanced suicidal erythrocyte death in mice carrying a loss-of-function mutation of the adenomatous polyposis coli gene. J. Cell Mol. Med. 2012, 16, 1085-1093.

90. Birka, C.; Lang, P.A.; Kempe, D.S.; Hoefling, L.; Tanneur, V.; Duranton, C.; Nammi, S.; Henke, G.; Myssina, S.; Krikov, M.; et al. Enhanced susceptibility to erythrocyte "apoptosis" following phosphate depletion. Pflugers Arch. 2004, 448, 471-477.

91. Foller, M.; Kasinathan, R.S.; Koka, S.; Huber, S.M.; Schuler, B.; Vogel, J.; Gassmann, M.; Lang, F. Enhanced susceptibility to suicidal death of erythrocytes from transgenic mice overexpressing erythropoietin. Am. J. Physiol. Regul. Integr. Comp. Physiol. 2007, 293, R1127-R1134.

92. Foller, M.; Mahmud, H.; Koka, S.; Lang, F. Reduced $\mathrm{Ca}^{2+}$ entry and suicidal death of erythrocytes in pdk1 hypomorphic mice. Pflugers Arch. 2008, 455, 939-949.

93. Kucherenko, Y.V.; Wagner-Britz, L.; Bernhardt, I.; Lang, F. Effect of chloride channel inhibitors on cytosolic $\mathrm{Ca}^{2+}$ levels and $\mathrm{Ca}^{2+}$-activated $\mathrm{k}+$ (gardos) channel activity in human red blood cells. J. Membr. Biol. 2013, 246, 315-326.

94. Shaik, N.; Lupescu, A.; Lang, F. Inhibition of suicidal erythrocyte death by probucol. J. Cardiovasc. Pharmacol. 2013, 61, 120-126.

95. Sinha, A.; Singh, A.; Satchidanandam, V.; Natarajan, K. Impaired generation of reactive oxygen species during differentiation of dendritic cells (dcs) by mycobacterium tuberculosis secretory antigen (mtsa) and subsequent activation of mtsa-dcs by mycobacteria results in increased intracellular survival. J. Immunol. 2006, 177, 468-478.

(C) 2014 by the authors; licensee MDPI, Basel, Switzerland. This article is an open access article distributed under the terms and conditions of the Creative Commons Attribution license (http://creativecommons.org/licenses/by/4.0/). 